\title{
PENGARUH VARIASI KONSENTRASI DAN LAMA PERENDAMAN ASAM LAKTAT TERHADAP KADAR GLUKOSA DAN KUALITAS TEPUNG UWI (DIOSCOREAALATA)
}

\author{
Nasrul Rofiah Hidayati \\ IKIP PGRI MADIUN, Madiun, 63118 \\ Email : nasrul.rofiah@gmail.com
}

\begin{abstract}
Penelitian ini bertujuan untuk mengetahui adanya pengaruh variasi konsentrasi dan lama perendaman asam laktat terhadap kadar glukosa dan kualitas tepung uwi (dioscoreaalata). Metode penelitian menggunakan Rancangan Acak Lengkap (RAL) dengan factorial $3 \times 3$ dan tiga kali ulangan. Faktor pertama variasi konsentrasi (K) meliputi $1 \%, 1,5 \%, 2 \%$, factor kedua lama perendaman (L) meliputi 60 menit, 90 menit, 120 menit. Pengambilan data dengan menghitung kadar glukosa menggunakan metode titrasi menggunakan $\mathrm{Na}_{2} \mathrm{~S}_{2} \mathrm{O}_{3}$ dan uji organoleptik meliputi warna, bau, tekstur dan tingkat kesukaan kepada 15 panelis dengan menggunakan angket tertutup. Analisis data menggunakan analisis varian (anava) dua jalur melalui SPSS versi 17.0 dengan taraf signifikan 0,05, kemudian jika signifikan akan dilanjutkanuji BNT atau LSD. Hasil analisis menunjukkan variasi konsentrasi berpengaruh terhadap kadar glukosa $(\mathrm{P}=0,000<$ $0,05)$. Lama perendaman berpengaruh terhadap kadar glukosa $(\mathrm{P}=0,000<0,05)$. Terdapat pengaruh interaksi variasi konsentrasi dan lama perendaman terhadap kadar glukosa $(\mathrm{P}=$ $0,013<0,05$ ). Kadar glukosa tertinggi terdapat pada perlakuan $\mathrm{K}_{1} \mathrm{~L}_{1}$ (konsentrasi $1 \%$ dan lama perendaman 60 menit), sedangkan kadar glukosa terendah pada perlakuan $\mathrm{K}_{3} \mathrm{~L}_{2}$ dan $K_{3} L_{3}$ pada perendaman 120 menit.Hasil uji organoleptik yang disukai pada perlakuan $K_{3} L_{3}$ karena bau khas uwi hilang, warna lebih putih, tekstur sangat lembut dan kadar glukosanya rendah.
\end{abstract}

Kata Kunci : Asam Laktat, Uwi (Dioscoreaalata), Kadar Glukosa

\section{PENDAHULUAN}

Ketergantungan masyarakat Indonesia terhadap tepung terigu dalam kehidupan sehari-hari sangat besar. Produksi tepung terigu berasal dari gandum yang diimpor. Berdasarkan data Disperindag, (2012) impor gandum tahun 2010 tercatat 4,8 ton. Tahun 2011 angkanya naik menjadi 5,2 ton dan Tahun 2012 mengalami kenaikan hingga $11 \%$ menjadi 5,8 ton. Sedangkan konsumsi tepung terigu Tahun 2011 mencapai 4,6 juta ton lebih tinggi dari 2010 yaitu sebanyak 4,3 juta ton. Indonesia memiliki sumber pangan lokal yang tersedia cukup banyak dan belum dimanfaatkan secara optimal. Oleh karena itu, perlu mengurangi ketergantungan masyarakat terhadap tepung terigu dengan mensubsitusi bahan pangan lokal yang ada di Indonesia. Salah satu bahan pangan lokal yang melimpah dan berpotensi untuk dimanfaatkan secara optimal adalah uwi (Dioscorea alata). Uwi juga dapat dimanfaatkan untuk tepung.

Upaya perbaikan kualitas tepung dapat dilakukan dengan memodifikasi sifat-sifat fungsional. Salah satu cara modifikasi untuk mempengaruhi sifat fungsional ialah perendaman. Perendaman atau fermentasi spontan dilaporkan dapat memperbaiki sifat reologi pati ( $\mathrm{Lu}$ et al., 2003 dalam Erning, Harijono, Bambang., 2012). Asam laktat tidak berbahaya jika masuk dalam tubuh manusia lewat makanan atau 
minuman yang dikonsumsi, karena pada dasarnya dalam tubuh manusia terdapat asam laktat dan asam laktat tersebut dapat diubah menjadi energi. Modifikasi kimia tepung secara asam dibuat dengan cara menghidrolisi pati yang terdapat dalam tepung menggunakan asam. Reaksi dasar pemotongan ikatan dari amilosa dan amilopektin,sehingga ukuran molekul pati menjadi lebih rendah. Uwi mengandung 19,8 g karbohidrat dan glukosa merupakan salah satu jenis dari karbohidrat. Mulyono HAM (2007: 151) menyebutkan glukosa merupakan salah satu tipe monosakarida dengan rumus $\mathrm{C}_{6} \mathrm{H}_{12} \mathrm{O}_{6}$. Glukosa disebut juga dektrosa karena strukturnya sebagian besar berada dalam bentuk D- yakni D-glukosa. Berdasarkan latar belakang masalah di atas maka dapat dirumuskan masalah sebagai berikut :

1. Adakah pengaruh variasi konsentrasi asam laktat terhadap kandungan glukosa pada tepung uwi (Dioscorea alata)?

2. Adakah pengaruh lama perendaman asam laktat terhadap kandungan glukosa pada tepung uwi (Dioscorea alata)?

3. Adakah interaksi variasi konsentrasi dan lama perendaman terhadap kandungan glukosa pada tepung uwi (Dioscorea alata)?

4. Adakah pengaruh variasi konsentrasi dan lama perendaman terhadap kualitas tepung uwi (Dioscorea alata)?

\section{METODE PENELITIAN}

Penelitian ini bersifat eksperimen dan menggunakan metode rancangan Acak Lengkap (RAL) disusun dengan 2 faktorial dan 3 kali ulangan. Penelitian ini dilakukan dengan pendekatan kuatitatif dan untuk mengetahui konsentrasi dan lama perendaman asam laktat yang tepat untuk kandungan glukosa yang rendah sehingga menghasilkan tepung yang memeliki kualitas lebih baik. Sedangkan Pengambilan data kualitas tepung dilakukan melalui uji organoleptik dengan melibatkan 15 orang panelis. Data diperoleh dari penyebaran angket kepada panelis. Angket yang digunakan adalah angket tertutup. Parameter yang diamati adalah warna, bau dan tekstur. Faktor perlakuan meliputi faktor pertama variasi konsentrasi asam laktat dan faktor kedua yaitu variasi lama perendaman. Kombinasi perlakuan dapat dilihat pada tabel 1 sebagai berikut :

Tabel 1. Kombinasi perlakuan

Keterangan :

\begin{tabular}{llll}
\hline Perlakuan & \multicolumn{3}{l}{ Lama perendaman $(\mathrm{L})$} \\
\hline Konsentrasi $(\mathrm{K})$ & $\mathrm{L}_{1}$ & $\mathrm{~L}_{2}$ & $\mathrm{~L}_{3}$ \\
\hline $\mathrm{K}_{1}$ & $\mathrm{~K}_{1} \mathrm{~L}_{1}$ & $\mathrm{~K}_{1} \mathrm{~L}_{2}$ & $\mathrm{~K}_{1} \mathrm{~L}_{3}$ \\
\hline $\mathrm{K}_{2}$ & $\mathrm{~K}_{2} \mathrm{~L}_{1}$ & $\mathrm{~K}_{2} \mathrm{~L}_{2}$ & $\mathrm{~K}_{2} \mathrm{~L}_{3}$ \\
\hline $\mathrm{K}_{3}$ & $\mathrm{~K}_{3} \mathrm{~L}_{1}$ & $\mathrm{~K}_{3} \mathrm{~L}_{2}$ & $\mathrm{~K}_{3} \mathrm{~L}_{3}$ \\
\hline
\end{tabular}

$\mathrm{K}(\mathrm{K} 1-\mathrm{K} 3) \quad$ : Konsentrasi asam laktat ( 1\%, 1,5 \%, $2 \%$ )

L (L1-L3) : Lama perendaman (60, 90, 120 menit ) 


\section{HASIL DAN PEMBAHASAN}

\section{Variasi Konsentrasi}

Hasil analisis uji hipotesis dengan menggunakan analisis anava 2 jalur menunjukkan bahwa konsentrasi dan lama perendaman berpengaruh nyata terhadap kadar glukosa, pada perlakuan konsentrasi 90 menit $\left(\mathrm{K}_{3} \mathrm{~L}_{2}\right)$ dan perlakuan konsentrasi 120 menit $\left(\mathrm{K}_{3} \mathrm{~L}_{3}\right)$ memiliki rata-rata kadar glukosa terendah yaitu $1,8 \%$. Hal ini dikarenakan semakin tinggi konsentrasi asam laktat maka semakin banyak polisakarida yang terhidrolisis dan yang larut. Polisakarida berupa amilosa yang terhidrolisis dan terlarut semakin banyak maka menyebabkan gula reduksi pada tepung uwi termodifikasi semakin sedikit. Hasil penelitian ini sesuai pendapat Atichokuidomchaia, et al., (2000) (dalam Puddjihastuti, 2010) menyatakan molekul amilosa mudah terpecah dibandingkan dengan molekul amilopektin sehingga saat hidrolisa asam berlangsung akan menurunkan gugus amilosa. Hasil uji kadar glukosa tepung uwi dapat dilihat pada gambar berikut :

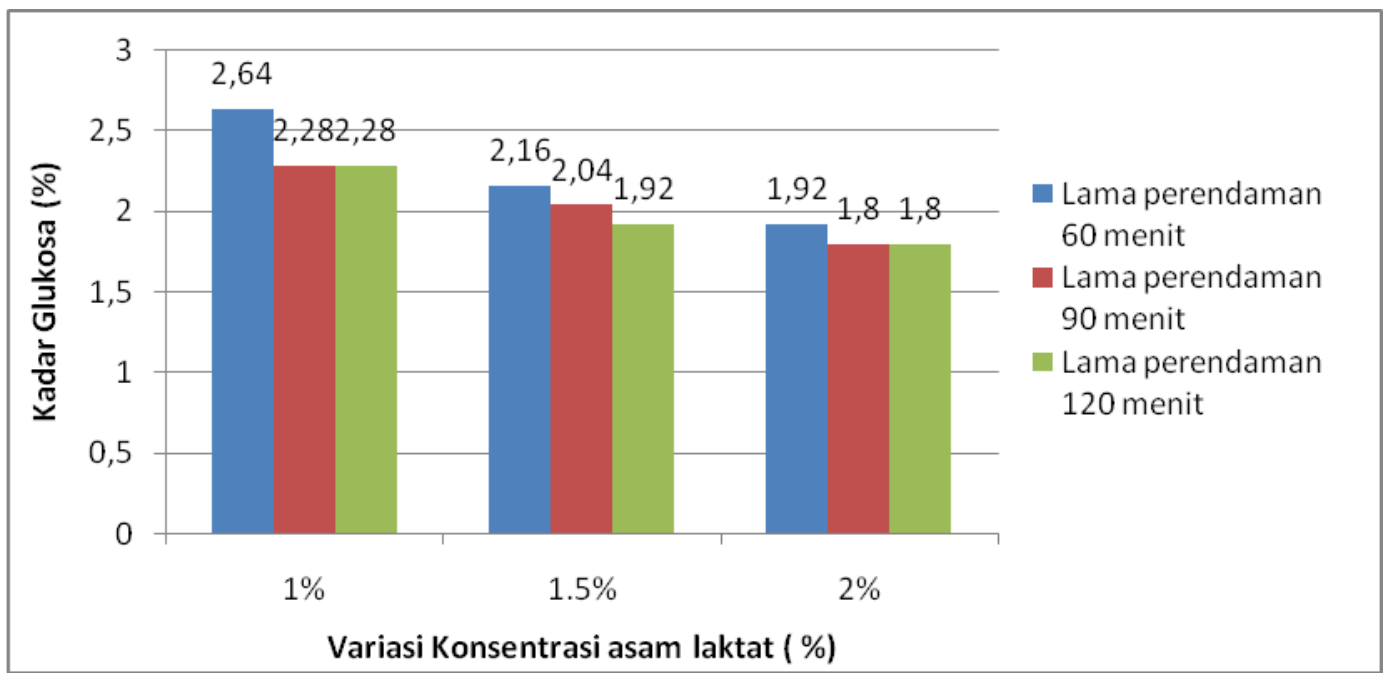

Gambar 1 : Histogram hasil uji kadar glukosa tepung uwi

Penurunan kadar glukosa terjadi pada setiap perlakuan, meskipun ada beberapa perlakuan yang menunjukkan kadar glukosa yang sama, diantaranya yaitu perlakuan konsentrasi $1 \% \quad\left(\mathrm{~K}_{1} \mathrm{~L}_{2}\right.$ dan $\mathrm{K}_{1} \mathrm{~L}_{3}$ ) memiliki kadar glukosa sebesar

\section{Lama Perendaman}

Hasil analisis hipotesis 2 jalan menunjukkan bahwa lama perendaman berpengaruh nyata terhadap kadar glukosa. Perlakuan perendaman 60 menit $\left(\mathrm{K}_{1} \mathrm{~L}_{1}\right)$ memiliki rata-rata kadar glukosa tertinggi dan lama perendaman 120 menit $\left(\mathrm{K}_{3} \mathrm{~L}_{2}\right.$ dan $\left.\mathrm{K}_{3} \mathrm{~L}_{3}\right)$ memiliki ratarata kadar terendah. Penurunan kadar glukosa disebabkan oleh terhidrolisisnya
2,88\%. Kemudian perlakuan $\mathrm{K}_{2} \mathrm{~L}_{3}$ dan $\mathrm{K}_{3} \mathrm{~L}_{1}$ memiliki kadar glukosa $1,92 \%$, dan yang terakhir adalah pada konsentrasi $120 \%\left(\mathrm{~K}_{3} \mathrm{~L}_{2}\right.$ dan $\left.\mathrm{K}_{3} \mathrm{~L}_{3}\right)$ juga memiliki kadar glukosa yang sama masing-masing $1,8 \%$.

amilosa yang tekandung dalam tepung uwi, sehingga amilosa akan mudah terlarut dan gula reduksi akan menurun. Semakin lama perendaman menyebabkan semakin menurun gula reduksi tepung uwi termodifikasi. Hasil penelitian ini sesuai dengan pendapat Demeate, et al., (1999) (dalam Pudjiahastuti, 2010) menyatakan pada 
perendaman asam laktat, asam berdifusi ke dalam granula pati akan membuat molekul-molekul pati menjadilebih kecil dan mudah larut dalam air.

Interaksi antara konsentrasi dan lama perendaman berpengaruh terhadap kadar glukosa tepung uwi, karena sig $0.013>0,05$. Menurut penelitian Feny Dwi Hartanti., et al, 2013 pada tepung sukun termodifikasi asam laktat,

\section{Uji organoleptik}

Berdasarkan hasil uji organoleptik tepung uwi yang meliputi warna, bau dan tekstur menunjukkan adanya pengaruh variasi konsentrasi terhadap warna dan bau tepung uwi, namun tidak ada pengaruh variasi konsentrasi terhadap tekstur tepung uwi. Hasil dari uji menunjukkan semakin besar konsentrasi asam laktat dan semakin lama perendaman maka semakin rendah kandungan gula reduksi yang disebabkan oleh banyak gugus amilosa yang telarut dalam air. Pada tepung uwi juga terjadi hal sama yaitu semakin besar konsentrasi asam laktat dan lama perendaman maka kadar glukosa pada tepung uwi semakin menurun.

organoleptik warna dari tepung uwi yang selanjutnya akan menentukan kualitas tepung uwi yang mengaju pada skala hedonik yaitu 4 (sangat putih), 3 (agak putih), 2 (putih kecoklatan), dan 1 ( coklat).

\section{Tabel 2 Nilai Organoleptik Tepung uwi}

\begin{tabular}{ccccc}
\hline Perlakuan & $\begin{array}{c}\text { Rat-rata } \\
\text { skor warna } \\
(\text { Bobot 30 })\end{array}$ & $\begin{array}{c}\text { Rata-rata } \\
\text { skor bau } \\
\text { Bobot 20 })\end{array}$ & $\begin{array}{c}\text { Rata-rata } \\
\text { skor tekstur } \\
(\text { Bobot 20 })\end{array}$ & Nilai \\
\hline $\mathbf{K}_{\mathbf{1}} \mathbf{L}_{\mathbf{1}}$ & 1,0 & 1,1 & 3,0 & 1,72 \\
\hline $\mathbf{K}_{\mathbf{1}} \mathbf{L}_{\mathbf{2}}$ & 1,7 & 1,26 & 3,13 & 1,98 \\
\hline $\mathbf{K}_{\mathbf{1}} \mathbf{L}_{\mathbf{3}}$ & 2,4 & 1,8 & 3,4 & 2,48 \\
\hline $\mathbf{K}_{\mathbf{2}} \mathbf{L}_{\mathbf{1}}$ & 2,46 & 1,93 & 3,33 & 2,55 \\
\hline $\mathbf{K}_{\mathbf{2}} \mathbf{L}_{\mathbf{2}}$ & 2,80 & 2,3 & 3,46 & 2,84 \\
\hline $\mathbf{K}_{\mathbf{2}} \mathbf{L}_{\mathbf{3}}$ & 2,6 & 2,3 & 3,5 & 2,77 \\
\hline $\mathbf{K}_{\mathbf{3}} \mathbf{L}_{\mathbf{1}}$ & 2,8 & 2,8 & 3,6 & 3,02 \\
\hline $\mathbf{K}_{\mathbf{3}} \mathbf{L}_{\mathbf{2}}$ & 3,0 & 3,0 & 3,66 & 3,18 \\
\hline $\mathbf{K}_{\mathbf{3}} \mathbf{L}_{\mathbf{3}}$ & 3,2 & 3,0 & 3,73 & 3,29 \\
\hline
\end{tabular}

Pada perlakuan $\mathrm{K}_{3} \mathrm{~L}_{3}$ (konsentrasi $2 \%$ dengan lama perendaman 120 menit) memiliki rata-rata tertinggi 3,2 berarti perlakuan $\mathrm{K}_{3} \mathrm{~L}_{3}$ termasuk dalam kategori warna agak putih menuju warna putih, sedangkan $\mathrm{K}_{1} \mathrm{~L}_{1}$ (konsentrasi $1 \%$ dengan konsentrasi $1 \%$ ) memiliki rata-rata terendah setelah perlakuan kontrol yaitu 1,3 berarti termasuk dalam warna coklat. Berdasarkan data tersebut dapat dilihat bahwa semakin tinggi konsentrasi dan lama perendaman asam laktat maka semakin meningkat warna tepung uwi menuju skala yang menunjukkan warna putih. Menurut Winarno (1992), reaksi maillard (pencoklatan non enzimatis) merupakan reaksi yang melibatkan gugus karbonil dan gugus amin. Salah satu cara untuk mencegah pencoklatan dilakukan dengan cara menghambat atau memblokir reaksi antara gugus karbonil atau gula pereduksi dengangugus amina dengan cara perendaman.

Hasil dari uji organoleptik bau dari tepung uwi mengaju pada skala hedonik yaitu 4 (sangat kuat), 3 (agak kuat), 2 (kurang kuat), dan 1 (tidak berbau). Pada perlakuan $\mathrm{K}_{3} \mathrm{~L}_{3}$ (konsentrasi 2\% dengan lama perendaman 120 menit) memiliki ratarata tertinggi 3,0 sedangkan $\mathrm{K}_{1} \mathrm{~L}_{1}$ (konsentrasi 1\% dengan konsentrasi 1\%) 
memiliki rata-rata terendah setelah perlakuan kontrol yaitu 1,1 . Hal tersebut menunjukkan bahwa konsentrasi dan lama perendaman asam laktat mempengaruhi bau dari tepung uwi dari mula-mula memiliki bau khas uwi yang kuat menjadi tidak berbau.

Hasil dari uji organoleptik tekstur dari tepung uwi yang mengacu pada skala hedonik yaitu 4 (lembut), 3 (agak lembut), 2 (agak kasar) dan 1 (Kasar) menunjukkan perlakuan $\mathrm{K}_{3} \mathrm{~L}_{3}$ (konsentrasi 2\% dengan lama perendaman 120 menit) memiliki ratarata tertinggi 3,73 berarti termasuk dalam agak lembut namun mendekati lembut, sedangkan $\mathrm{K}_{1} \mathrm{~L}_{1}$ (konsentrasi $1 \%$ dengan konsentrasi $1 \%$ ) memiliki rata-rata terendah yaitu 2,93 berarti mendekati skala 3 yang termasuk dalam tekstur agak lembut. Variasi konsentrasi dan lama perendaman tidak mempengaruhi secara signifikan terhadap tekstur tepung uwi karena pada setiap perlakuan memiliki rata-rata yang mendekati skala 3 dan 4 . Hal tersebut berarti tekstur tepung lembut. Dari hasil perhitungan nilai terjadi peningkatan pada setiap perlakuan, semakin besar konsentrasi dan lama perendaman, semakin tinggi nilai. Sehingga semakin besar konsentrasi dan lama perendaman, semakin tinggi tingkat kesukaan panelis dan semakin baik kualitas tepung.

\section{Interaksi Kadar Glukosa dan Nilai Organoleptik}

Tabel 3 Interaksi Kadar Glukosa dan Uji Organoleptic Tepung Uwi

\begin{tabular}{ccc}
\hline Perlakuan & Kadar glukosa (\%) & Nilai organoleptic \\
\hline $\mathbf{K}_{\mathbf{1}} \mathbf{L}_{\mathbf{1}}$ & 2,64 & 1,72 \\
\hline $\mathbf{K}_{\mathbf{1}} \mathbf{L}_{\mathbf{2}}$ & 2,28 & 1,98 \\
\hline $\mathbf{K}_{\mathbf{1}} \mathbf{L}_{\mathbf{3}}$ & 2,28 & 2,48 \\
\hline $\mathbf{K}_{\mathbf{2}} \mathbf{L}_{\mathbf{1}}$ & 2,16 & 2,55 \\
\hline $\mathbf{K}_{\mathbf{2}} \mathbf{L}_{\mathbf{2}}$ & 2,04 & 2,84 \\
\hline $\mathbf{K}_{\mathbf{2}} \mathbf{L}_{\mathbf{3}}$ & 1,92 & 2,77 \\
\hline $\mathbf{K}_{\mathbf{3}} \mathbf{L}_{\mathbf{1}}$ & 1,92 & 3,02 \\
\hline $\mathbf{K}_{\mathbf{3}} \mathbf{L}_{\mathbf{2}}$ & 1,8 & 3,18 \\
\hline $\mathbf{K}_{\mathbf{3}} \mathbf{L}_{\mathbf{3}}$ & 1,8 & 3,29
\end{tabular}

Pada perlakuan $\mathrm{K}_{1} \mathrm{~L}_{1}$ ( konsentrasi $1 \%$ dan lama perendaman 30 menit) merupakan kadar glukosa terendah dan juga memiliki nilai organoleptik terendah berarti kesukaan panelis rendah. Sedangkan nilai organoleptik tertinggi terdapat pada perlakuan $\mathrm{K}_{3} \mathrm{~L}_{3}$ ( konsentrasi 2\% dan lama perendaman 120 menit) yang juga memiliki kadar glukosa terendah. Semakin besar konsentrasi dan lama perendaman asam laktat, nilai organoleptik tepung uwi semakin tinggi. Sehingga semakin rendah kadar glukosa pada tepung uwi semakin tinggi nilai organoleptik tepung uwi tersebut. Berarti tingkat kesukaan panelis terhadap tepung uwi semakin tinggi jika kadar glukosa pada tepung uwi semakin rendah. Hal tersebut ditunjukkan pada perlakuan $\mathrm{K}_{3} \mathrm{~L}_{3}$ ( konsentrasi $2 \%$ dan lama perendaman 120 menit) yang memiliki kadar glukosa yang rendah namun nilai organoleptik tertinggi

\section{SIMPULAN}

Berdasarkan hasil analisa data menunjukkan bahwa variasi konsentrasi dan lama perendaman asam laktat berpengaruh nyata terhadap kadar glukosa pada tepung uwi. tepung 


\begin{abstract}
Terdapat interaksi antara variasi konsentrasi dan lama perendaman terhadap kadar glukosa uwi (Dioscorea alata). Berdasarkan uji organoleptik data menunjukkan bahwa variasi konsentrasi dan lama perendaman asam laktat berpengaruh terhadap kualitas tepung uwi. Semakin besar variasi konsentrasi dan lama perendaman asam laktat, semakin baik kualitas tepung uwi.
\end{abstract}

\section{SARAN}

Disarankan untuk melakukan penelitian pengembangan kadar glukosa dan kualitas tepung dengan sampel tepung uwi yang dibuat dalam pembuatan yang berbeda, selain itu pengembangan juga bisa menggunakan sampel tepung dari umbi-umbian yang berbeda.

\section{DAFTAR PUSTAKA}

Erning Indrastuti, Harijono, Bambang Susilo. 2012. Karakteristik Tepung Uwi Ungu (Dioscorea alata L.) yang Direndam Dan Dikeringkan Sebagai Bahan Edible Paper. (http://Fjtp.ub.ac.id ) diakses tanggal 20 Maret 2014

Feny Dwi Hartanti. Bambang sigit amanto dan Dimas Rahardian A.M. 2013. Kajian Karakteristik Fisikokimia tepung sukun (Artocarpus communis) Termodifikasi Deangan Variasi Konsentrasi dan Lama Perendaman Asam Laktat. (http://ilmupangan.fp.uns.ac.i d/attachments/article/298/8.\% 20KAJIAN\%20KARAKTER ISTIK\%20FISIKOKIMIA\%2 0TEPUNG\%20SUKUN\%20 ASAM\%20LAKTAT\%20\%2 8Feny\%20Dwi\%20Hartanti\% 29.pdf di akses tanggal 12 Februari 2014.

Hehmaning Prabasini, , Dwi Ishartani dan dimas Rahardian. Kajian Sifat Kimia dan Fisik Tepung Labu Kuning (Cucubita moschata) dengan Perlakuan Blanching dan perendaman dalam natrium metabisulfat $\left(\mathrm{Na}_{2} \mathrm{~S}_{2} \mathrm{O}_{3}\right)$. http://ilmupangan.fp.uns.ac.id ) tanggal 13 Maret 2014.

Isti Pudhihastuti. 2010. Pengembangan Proses Inovatif Kombinasi Raksi Hidrolisis Asam dan Reaksi Photokimia UV Untuk Produksi Pati Termodifikasi dari

Tapioka.(http://undip.ac.id25 1921isti.pdf ) diakses tanggal 11 Februari 2014.

John M deMan.1989. Kimia makanan (Prinsiples of Foof Chemistry). Terjemahan oleh Prof. Dr. Kokasih Padmawinata. 1997. Bandung: ITB

Kementerian Perdagangan Republik Indonesia. 2012. Tinjauan Pasar Tepung Terigu. (http://Fews.kemendag.go.id) 
diakses tanggal 17 Februari 2014

Mulyono. 2007. Kamus Kimia.

Jakarta: Bumi Aksara

Sugiyono. 2013. Metode Penelitian Pendidikan (Pendekatan Kuantitatif, Kualitatif, dan $R$ $\& D)$. Bandung: Alfabeta.

Winarno, F.G. 1997. Kimia Pangan Dan Gizi. Jakaarta: Gramedia Pustaka Utama

Winarno, F.G. 2002. Kimia Pangan Dan Gizi. Jakaarta: Gramedia Pustaka Utama 